\title{
Clumped isotope temperature calibration for calcite: Bridging theory and experimentation
}

\section{J.J. Jautzy ${ }^{1 *}$, M.M. Savard ${ }^{1}$, R.S. Dhillon ${ }^{2}$, S.M. Bernasconi ${ }^{3}$, A. Smirnoff ${ }^{1}$}

Abstract

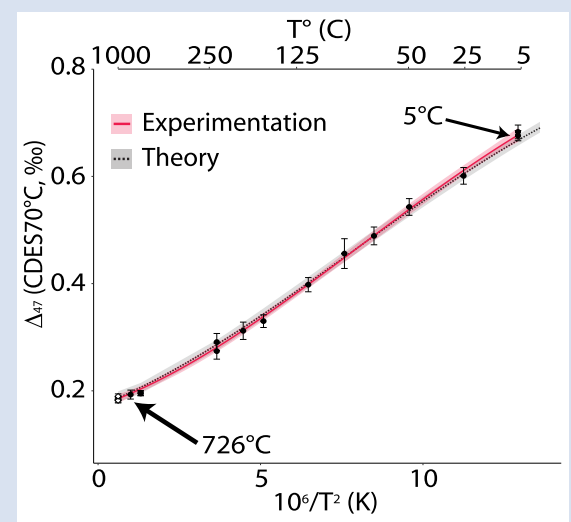

Clumped isotopes $\left(\Delta_{47}\right)$ analysis in carbonates is becoming widespread across the geochemical community as a geothermometer that also allows for the reconstruction of the precipitating fluid $\delta^{18} \mathrm{O}$ composition. While initial $\Delta_{47}$-temperature relationship discrepancies between laboratories have been considerably reduced over the past 10 years, theoretical temperature calibration and laboratory experimental efforts have still not converged to common ground. Moreover, a lack of high temperature anchor points has weakened its application to high temperature calcite formation. Here we present a temperature calibration for carbonate clumped isotopes between 5 and $726^{\circ} \mathrm{C}$, using synthetically precipitated and heated calcites, to extend the calcite $\Delta_{47}$-temperature calibration to higher temperatures. By showing a strong agreement between the empirical calibration proposed here, theoretical and all recently published T-calibrations made using a full carbonate referencing scheme, this study: (1) provides a calibration allowing more precise application in high temperature geological systems, (2) further supports the improvement of inter-laboratory comparison by using carbonate standards, (3) reconciles empirical temperature calibrations with theory.

Received 7 February 2020 | Accepted 26 May 2020 | Published 7 July 2020

\section{Introduction}

Clumped isotope measurements on $\mathrm{CO}_{2}$ extracted through acidification of carbonates has evolved over the past 15 years as a tool to probe directly the temperature (T) and the parent fluid oxygen isotope composition $\left(\delta^{18} \mathrm{O}\right)$ of precipitates (Schauble et al., 2006). This is done by analysing the excess abundance of ${ }^{13} \mathrm{C}-{ }^{18} \mathrm{O}$ bonds in the crystal lattice relative to a stochastic distribution $\left(\Delta_{47}\right)$. This measurement has a direct link to the formation temperature of the carbonate crystal (Schauble et al., 2006) and, therefore, avoids needing to making potentially incorrect assumptions on the isotopic composition of the precipitating fluid as necessary when using the carbonate-water $\delta^{18} \mathrm{O}$ geothermometer (Urey, 1947). The pioneering work of Ghosh et al. (2006) reported the first experimental calibration of the $\Delta_{47}-\mathrm{T}$ relationship between 1 and $50{ }^{\circ} \mathrm{C}$. The use of $a b$ initio thermodynamic models (Schauble et al., 2006; Guo et al., 2009) allowed the calculation of the ${ }^{13} \mathrm{C}-{ }^{18} \mathrm{O}$ bond ordering in the carbonate crystal lattice as a function of formation temperature, theoretically grounding this geothermometer.

Since its inception, this $\Delta_{47}-\mathrm{T}$ calibration has been reproduced in different laboratories by measuring both natural (e.g., Kele et al., 2015; Breitenbach et al., 2018; Peral et al., 2018;
Daëron et al., 2019) and synthetic (e.g., Dennis and Schrag, 2010; Passey and Henkes, 2012; Defliese et al., 2015; Kluge et al., 2015) calcites. Improvements of the T-calibration have been based on refining the preparation and analytical techniques (e.g., sample preparation automatisation, sample size reduction), establishing an absolute scale (carbon dioxide equilibrium scale at $25{ }^{\circ} \mathrm{C}$ acid digestion temperature; $\overline{\mathrm{CDES}} 25^{\circ} \mathrm{C}$; Dennis et al., 2011), increasing the number of replicates per anchor points, and abating the analytical artefacts inherent to clumped isotopic measurements. While these advances have considerably reduced the differences observed between the T-calibrations produced in independent laboratories, significant differences still remain. More recently, the clumped isotope community has put effort into understanding the causes of the remaining inter-laboratory differences. Practitioners have also promoted the principle of similar treatment for standards and unknown samples as a mean of improving inter-laboratory comparisons (Bernasconi et al., 2018). However, a lack of temperature calibration points above $100{ }^{\circ} \mathrm{C}$ and large differences at higher temperatures persist, weakening the application of this thermometer to high temperature geological systems. More importantly, none of the published T-calibrations can reconcile theory and experimentation and the non-linearity of the theoretical $\Delta_{4}-\mathrm{T}$

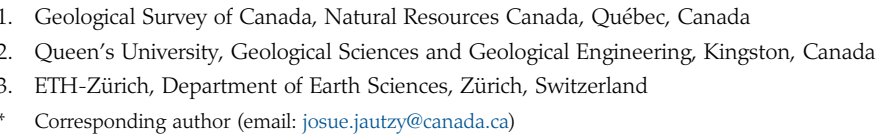




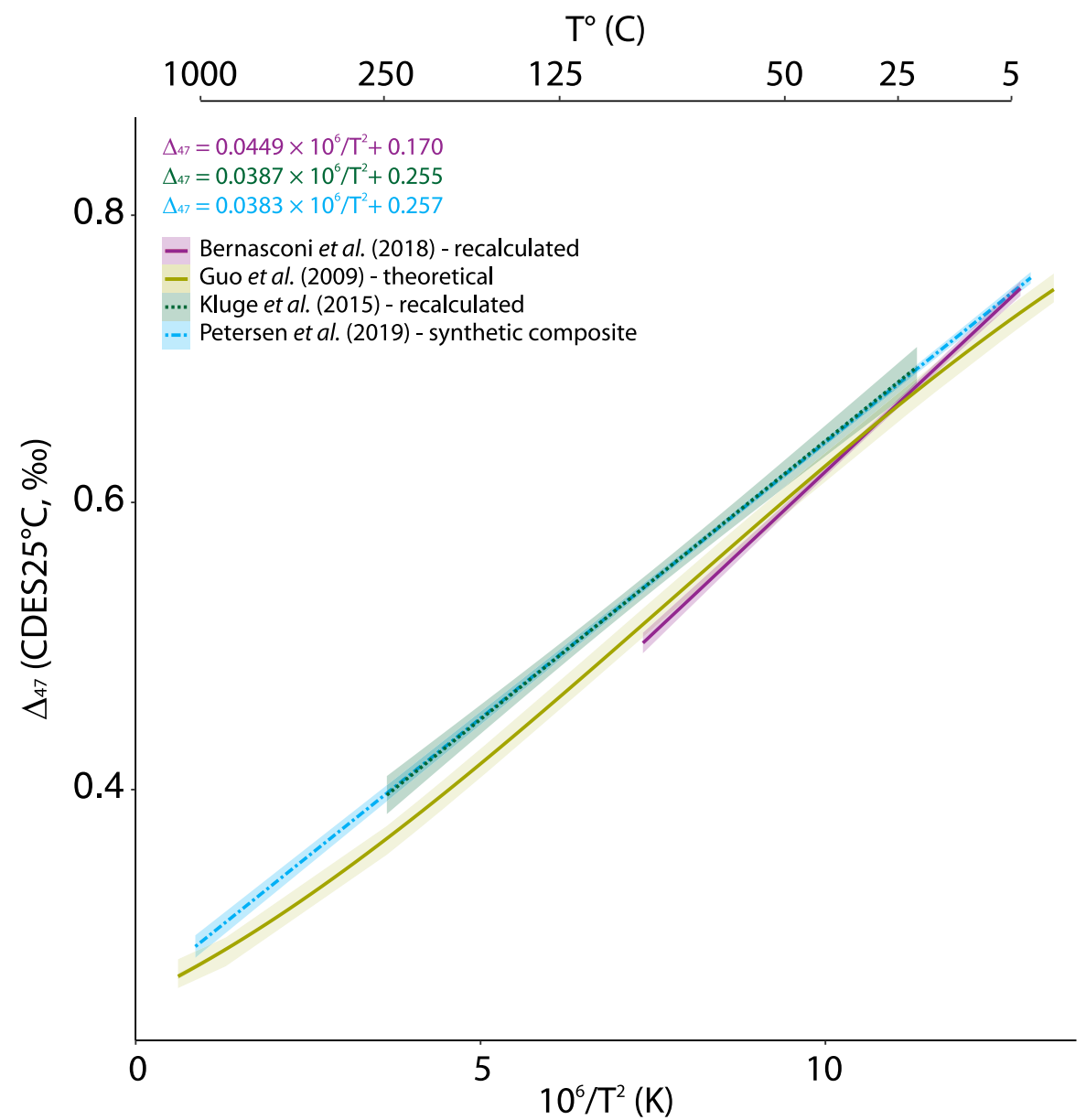

Figure $1 \Delta_{47}-\mathrm{T}$ linear relationships in the CDES25 $5^{\circ} \mathrm{C}$ for the empirical and theoretical calibrations (see text for details). Lines represent the regression models based on all replicates, and shaded envelopes show their $95 \%$ confidence intervals $(\mathrm{Cl})$. For more information on the reprocessing of these different datasets see Supplementary Information S-6.

mathematical relationship (Guo et al., 2009) also observed experimentally for dolomite (Müller et al., 2019) has not been reproduced empirically at high temperatures for calcite (Fig. 1).

Apart from the challenges inherent to comparing T-calibrations directly based upon different standardisation strategies, the differences (i.e. slope $p$ values $<1 \times 10^{-4}$ and intercept $p$ values $<1 \times 10^{-4}$; Supplementary Information S-1, Table S-1) observed between the latest composite (Petersen et al., 2019), the fully carbonate-based standardised (Kele et al., 2015) recalculated by Bernasconi et al. (2018), and the theoretical T-calibrations (Guo et al., 2009) could be due to the strong influence of the high temperature calcite calibration points (Passey and Henkes, 2012; Kluge et al., 2015) used in the data compilation effort of Petersen et al. (2019) (Fig. 1). Some additional effects might have influenced the high temperature precipitates from Kluge et al. (2015) (Supplementary Information S-2, Fig. S-1) and the re-ordering experiments in Passey and Henkes (2012) (e.g., incomplete solid state re-ordering), potentially influencing the slope of this composite $\Delta_{47}-$ T relationship (Petersen et al., 2019).

This study attempts to bridge the gap between the fully stochastic isotope distribution reached at high temperature and the large number of low to medium temperature points produced since the onset of this new geochemical tool. We choose to work solely on calcites to avoid potential biases due to specific acid fractionation factors (AFF) when using different carbonates (i.e. aragonite, dolomite, siderite) as theoretically predicted (Guo et al., 2009) and shown by recent experimental work (Müller et al., 2017a; van Dijk et al., 2019) at the temperature of acid digestion used in this study $\left(70^{\circ} \mathrm{C}\right)$. We also took advantage of the growing number of laboratories that adopted a fully carbonate-based standardisation of $\Delta_{47}$ measurements identical to the treatment used here - to evaluate further the improvement brought by this standardisation scheme to interlaboratory comparison.

\section{Methodology}

Synthetic precipitates. Precipitation of synthetic calcites was performed using high pressure and temperature reaction cells $\left(70-250{ }^{\circ} \mathrm{C}\right)$ and passive diffusion techniques $\left(5-70{ }^{\circ} \mathrm{C}\right)$ (Supplementary Information S-3, S-4, Table S-2, Fig. S-2) (Dennis and Schrag, 2010; Defliese et al., 2015). Briefly, solutions of $\mathrm{NaHCO}_{3}$ and $\mathrm{CaCl}_{2}$ were equilibrated separately at the target temperature for 24 to $144 \mathrm{hr}$ prior to mixing. The solutions were then left to precipitate for at least $24 \mathrm{hr}$. We carried out nearequilibrium precipitation by keeping the calcite saturation index below 2.5 and verifying the $\delta^{18} \mathrm{O}$ values of the precipitates relative to the $\delta^{18} \mathrm{O}$ of the water used $(-10.9 \%$; see Fig. S-1, Table S-2, Supplementary Information S-2, S-3). The production of the heated calcite (i.e. $\mathrm{CM} \gamma-5 ; 726^{\circ} \mathrm{C}$ ) is described in Schmid and Bernasconi (2010).

Measurements. Synthetic precipitates were analysed at the Delta-lab (Geological Survey of Canada) using a MAT 253 (Thermo Scientific, Bremen, Germany) equipped with six shielded faraday cups $(\mathrm{m} / \mathrm{z}=44-49)$ and an additional half-mass 
detector at $\mathrm{m} / \mathrm{z}=47.5$ for live background monitoring. The preparation of carbonate was performed with a KIEL-IV carbonate device (Thermo Scientific, Bremen, Germany) modified according to Schmid and Bernasconi (2010). The sample is first acidified for $500 \mathrm{~s}$ with 3 drops of $104 \%$ phosphoric acid prepared following the method of Burman et al. (2005). Evolved $\mathrm{CO}_{2}$ and $\mathrm{H}_{2} \mathrm{O}$ are trapped continuously at liquid $\mathrm{N}_{2}\left(\mathrm{LN}_{2}\right)$ temperature followed by a $60 \mathrm{~s}$ of non-condensable gas pumping. The $\mathrm{CO}_{2}$ is then released at $-100{ }^{\circ} \mathrm{C}$ and cryopumped through a Porapak trap surrounded by $\mathrm{Ag}$ wool held at $-14{ }^{\circ} \mathrm{C}$ into a micro-volume at $\mathrm{LN}_{2}$ temperature. The purified $\mathrm{CO}_{2}$ is then released into the ion source of the mass spectrometer through an inert capillary. $\delta^{18} \mathrm{O}, \delta^{13} \mathrm{C}$, and $\delta_{47}$ data were acquired simultaneously using the long integration dual inlet (LIDI) method (Müller et al., 2017b).

Each measurement comprises 70 cycles of $10 \mathrm{~s}$ integrations of the unknown gas followed by a similar integration strategy of the working gas $\left(\delta^{13} \mathrm{C}_{\mathrm{VPDB}}=-4.5 \%\right.$ o, $\delta^{18} \mathrm{O}_{\mathrm{VPDB}}=$ $-14.05 \%$ o). Each synthetic calcite measurement was replicated at least 20 times (80-100 $\mu \mathrm{g}$ aliquots) in order to achieve good precision for the evaluation of the $\Delta_{47}-\mathrm{T}$ relationship. Error estimation is reported as $95 \%$ confidence interval (CI) of all replicates.

Data processing. Raw beam intensities were imported into Easotope (John and Bowen, 2016) for calculation of the $\Delta_{47}$. The IUPAC parameter set (Brand et al., 2010) was used to correct for ${ }^{17} \mathrm{O}$ interferences (Daëron et al., 2016; Schauer et al., 2016). We adopted a fully carbonate-based calibration scheme by interspersing $50 \%$ of carbonate standards developed at
ETH-Zurich (Meckler et al., 2014) in every analytical session, and by keeping similar average sample and standard sizes. The recalculated values (IUPAC parameter) of the different standards (ETH1-4) were used (Bernasconi et al., 2018) with an external long term standard deviation of 37 ppm. ETH-1 and ETH-2 were used to correct for non-linearity effects in the ion source, ETH-1, 2 and 3 aided with constructing the empirical transfer function (ETF) for translation of the measurements to the CDES, and ETH-4 was treated as an unknown for data acquisition and processing monitoring. The calibration was made on a running window of 56 standards before and after each unknown to correct for drift in ion source stability. Minor negative background correction was performed using the pressure baseline correction (Bernasconi et al., 2013) after every 46 replicates using high voltage scans made from 5 to $25 \mathrm{~V}$ intensities $(\mathrm{m} / \mathrm{z}=44)$, in $5 \mathrm{~V}$ increments, to produce a correction function that can be applied to the decaying beam intensity inherent to the LIDI method of measurement. Discussion on the effect of linearities on the ETH carbonate standardisation scheme can be found in the Supplementary Information S-5.

\section{Results and Discussion}

Following the mentioned methodologies, we produced a linear $\mathrm{T}-\Delta_{47}$ calibration over the temperature range of 5 to $250{ }^{\circ} \mathrm{C}$ (Fig. 2).

To evaluate the efficiency of the ETH carbonate standardisation scheme in improving inter-laboratory comparisons, we compiled the T-calibrations from this study and recently

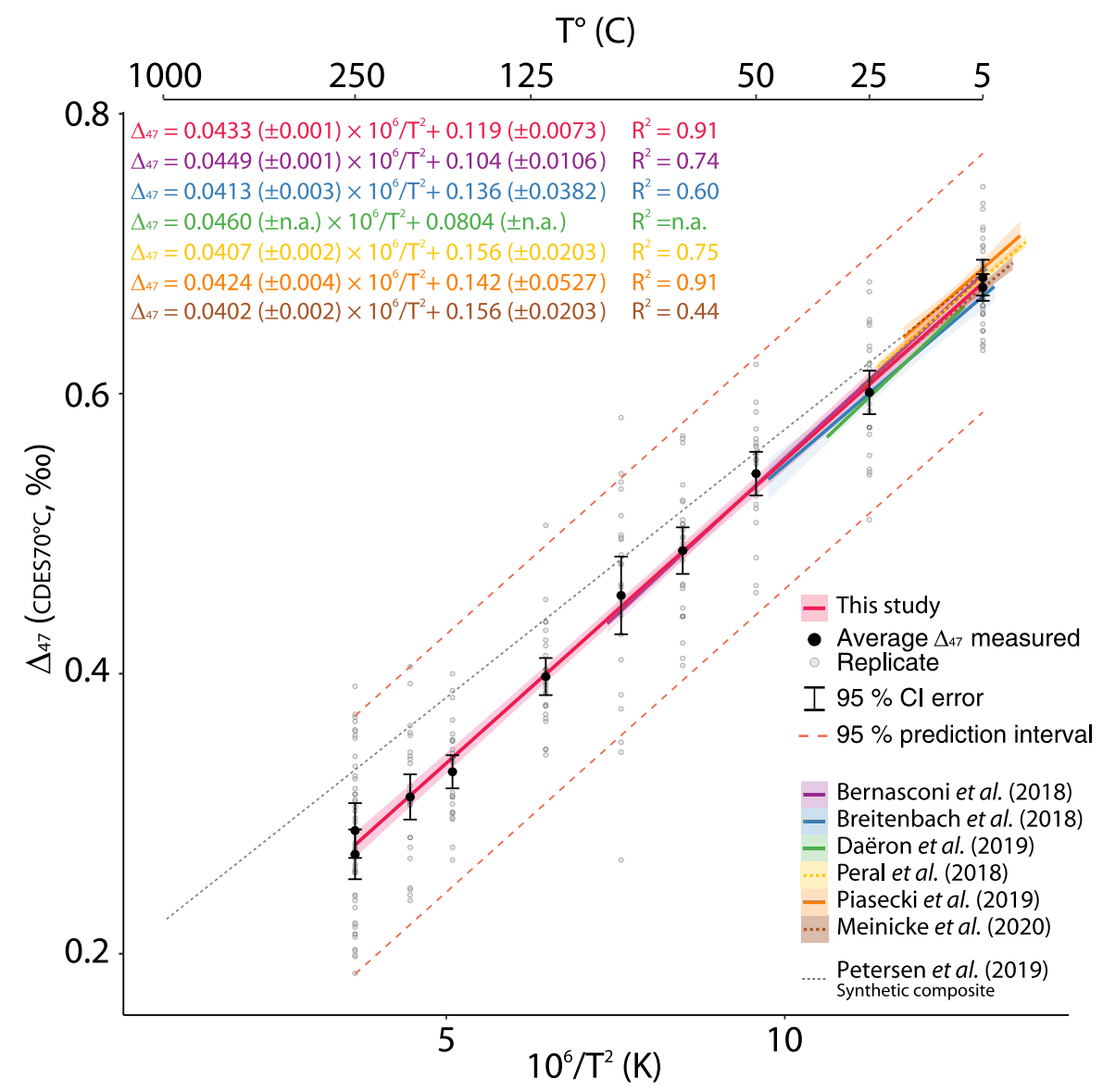

Figure $2 \Delta_{47}-\mathrm{T}$ linear relationship in the CDES70 ${ }^{\circ} \mathrm{C}$ for the studies fully referenced to ETH carbonate standards; lines represent each study's linear models, with shaded envelopes representing their respective $95 \% \mathrm{Cl}$. For more information on the reprocessing of the different datasets, see Supplementary Information S-6. 
published $\Delta_{47}-\mathrm{T}$ relationships standardised with ETH carbonates (Bernasconi et al., 2018; Breitenbach et al., 2018; Peral et al., 2018; Daëron et al., 2019; Piasecki et al., 2019; Meinicke et al., 2020; Fig. 2) in the $\mathrm{CDES} 70^{\circ} \mathrm{C}$. This approach avoids the potential propagation of errors due to the use of somewhat loosely constrained AFF conversions. An analysis of covariance on the different slopes and $y$ intercepts of the $\Delta_{47}-\mathrm{T}$ relationships reveals strong similarities at the $95 \% \mathrm{CI}$ (i.e. slope and $y$ intercept $p$ values $>0.05$; Table $\mathrm{S}-3$ ). This exercise confirms that the proposition to use a fully carbonate-based calibration scheme (Bernasconi et al., 2018) improves the comparison of data measured in different laboratories with various treatment, analytical methods and different types of calcite formation while avoiding the effects of the uncertainty in the AFF. Hence, this supports producing the following composite linear $\Delta_{47} \mathrm{~T}$ relationship with $\mathrm{T}$ in $\mathrm{K}$ (Fig. 2).

$$
\Delta_{47}\left(C D E S 70^{\circ} \mathrm{C}\right)=0.0435( \pm 0.0004) \times \frac{10^{6}}{T^{2}}+0.118( \pm 0.0042)
$$

We additionally plotted the composite calibration from Petersen et al. (2019) for qualitative comparison (Fig. 2). While partially overlapping within the $95 \% \mathrm{CI}$ error estimates of the low temperature calcite precipitates synthesised in this study, differences in $\Delta_{47}$ of up to $50 \mathrm{ppm}$ are observed between the two calibrations at temperatures above $90{ }^{\circ} \mathrm{C}$. These discrepancies at $\mathrm{ca} .200^{\circ} \mathrm{C}$ translate into temperature estimates differences of around $50{ }^{\circ} \mathrm{C}$, which can influence the interpretation of high temperature systems when using the clumped isotope geothermometer.

In an attempt to investigate the theoretical non-linear nature of the $\Delta_{47}-T$ relationship, we expanded the studied temperature range to the equivalent stochastic ${ }^{13} \mathrm{C}-{ }^{18} \mathrm{O}$ bonds distribution by adding measurements of the heated calcite CM $\gamma-5$ $\left(726^{\circ} \mathrm{C}\right.$ ) (Schmid and Bernasconi, 2010) and the data for the three stochastic calcites $\left(1000{ }^{\circ} \mathrm{C}\right)$ reported in Müller et al. (2017) (Fig. 3, Supplementary Information S-6).

The polynomial relationship from Guo et al. (2009) is projected into the $\mathrm{CDES} 70^{\circ} \mathrm{C}$ frame by replacing the $\Delta^{*}{ }_{47-63}$ $\left(=0.268 \%\right.$ o for a $25{ }^{\circ} \mathrm{C}$ acid digestion) with a $70{ }^{\circ} \mathrm{C} \Delta^{*}{ }_{47-63}$ (= $=0.184 \%$ \%) determined experimentally by Müller et al. (2017b) and updated to the IUPAC parameters (Supplementary Information S-6, S-7). While the theoretical $\Delta_{47}-\mathrm{T}$ polynomial relationship (Guo et al., 2009) fits relatively well with our empirical calibration curve at high temperature (i.e. within the $95 \% \mathrm{CI}$ ), our curve lies above the theoretical line and outside the $95 \% \mathrm{CI}$ at low temperature. When we modify the theoretical curve by integrating the dependency of the $\Delta^{*}{ }_{47-63}$ to the $\Delta_{63}$ of the reactant carbonates (Guo et al., 2009), a significant fit between the two polynomial curves is observed (i.e. $p$ value $=$ 0.96; Supplementary Information S-1), reconciling the experimentation with theory at the $95 \% \mathrm{CI}$ over the full temperature spectrum (Fig. 3). This, in addition to the significant similarities of all $\Delta_{47}$-T linear relationships (Fig. 2), further supports using the carbonate standardisation scheme for inter-laboratory

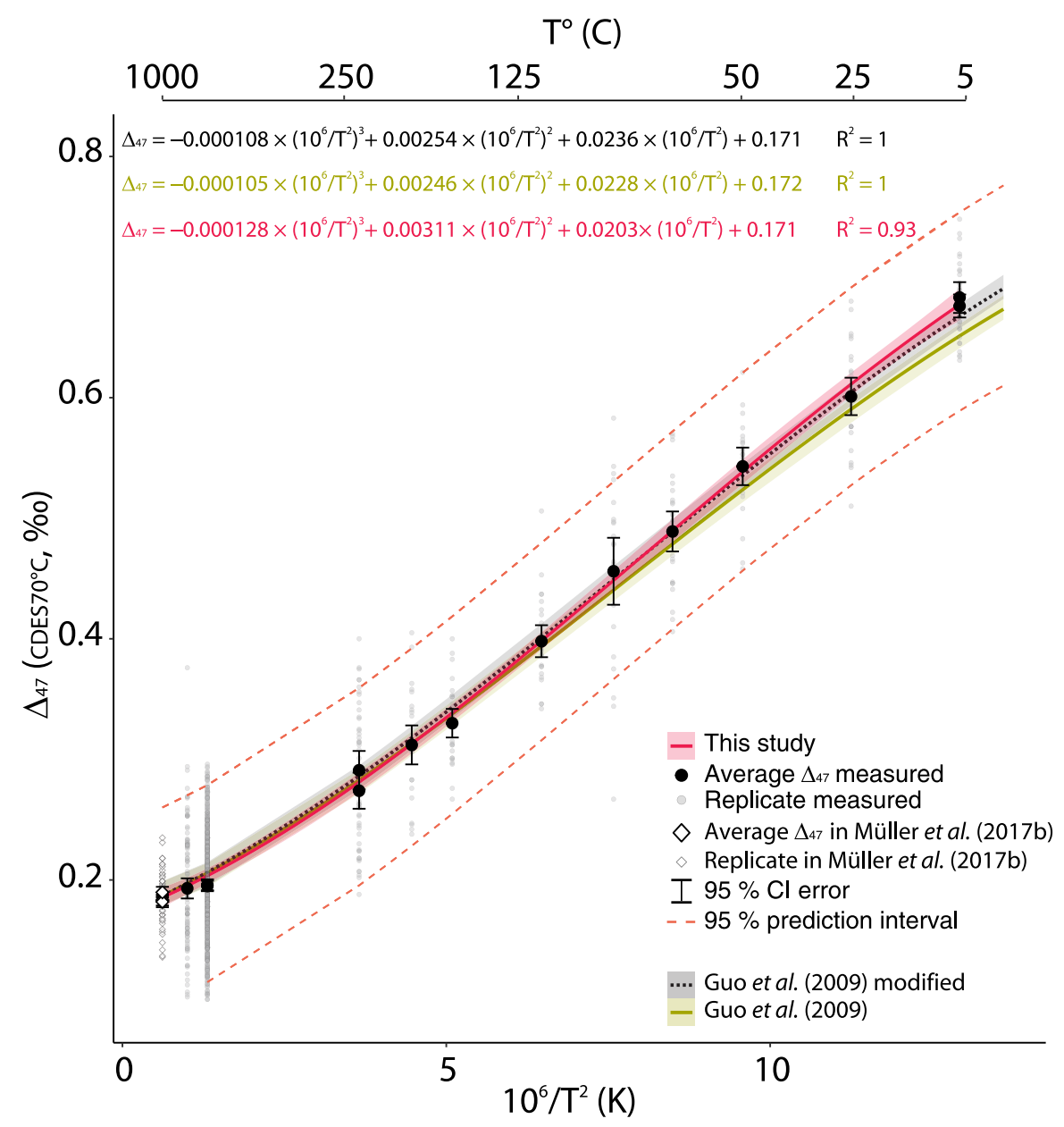

Figure $3 \Delta_{47}-\mathrm{T}$ third-order polynomial relationship $\left(\mathrm{CDES} 70^{\circ} \mathrm{C}\right)$ for this study, the theoretical, thermodynamic based relationship in Guo et al. (2009) and a modified version of this equation taking into account the dependence of the $\Delta^{*}{ }_{47-63}$ on the reactant $\Delta_{63}$ (35 ppm increase in $\Delta^{*}{ }_{47-63}$ per $1 \%$ increase in $\left.\Delta_{63}\right)$. ETH1 and $2\left(\right.$ i.e. $600^{\circ} \mathrm{C}$ ) are illustrated for visual comparison but are not included in the regression model. 
comparisons (Bernasconi et al., 2018; Peral et al., 2018; Meinicke et al., 2020). Moreover, this study provides an empirical $\mathrm{T}$-calibration agreeing with theory over the broadest temperature range to date. This new T-calibration, which can be applied by any laboratory using a carbonate-based standardisation of their measurements on calcite, may also serve for investigating geological contexts of calcite formation at high temperature.

\section{Acknowledgements}

This research was funded by the Lands and Minerals Sector of Natural Resources Canada under the joint framework of the Targeted Geosciences Initiatives and the Geo-mapping for Energy and Minerals programs. Marc Luzincourt is thanked for his assistance on $\Delta_{47}$ measurements in the Delta-lab and Pierre Masselot for statistical support. We thank Will Defliese, Nami Kitchen, Ury Ryb and John Eiler for advice and discussions that helped setting up this clumped isotope facility, Magali Bonifacie for discussions that lead to the preparation of this manuscript and Jason Ahad for providing comments that greatly improved this manuscript. Joep van Dijk as well as two anonymous reviewers and the editor Eric Oelkers are thanked for their comments that contributed to improve this manuscript. Natural Resources Canada Contribution No. 20190528.

Data Statement: Originally processed data are included in the references cited. The data acquired for this study has been archived in the EarthChem, ClumpDB database under the following doi: 10.26022/IEDA/111559.

\section{Editor: Eric H. Oelkers}

\section{Additional Information}

Supplementary Information accompanies this letter at http:// www.geochemicalperspectivesletters.org/article2021.

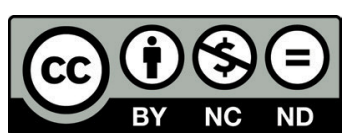

(C) 2020 The Authors. This work is distributed under the Creative Commons Attribution NonCommercial No-Derivatives 4.0 License, which permits unrestricted distribution provided the original author and source are credited. The material may not be adapted (remixed, transformed or built upon) or used for commercial purposes without written permission from the author. Additional information is available at http://www. geochemicalperspectivesletters.org/copyright-and-permissions.

Cite this letter as: Jautzy, J.J., Savard, M.M., Dhillon, R.S., Bernasconi, S.M., Smirnoff, A. (2020) Clumped isotope temperature calibration for calcite: Bridging theory and experimentation. Geochem. Persp. Let. 14, 36-41.

\section{References}

Bernasconi, S.M., Hu, B., Wacker, U., Fiebig, J., Breitenbach, S.F.M., RutZ, T. (2013) Background effects on Faraday collectors in gas-source mass spectrometry and implications for clumped isotope measurements. Rapid Communications in Mass Spectrometry 27, 603-612.

Bernasconi, S.M., Müller, I.A., Bergmann, K.D., BreitenbaCh, S.F.M., FernandeZ, A., Hodell, D.A., Jaggi, M., Meckler, A.N., Millan, I., Ziegler, M. (2018) Reducing Uncertainties in Carbonate Clumped Isotope Analysis Through Consistent Carbonate-Based Standardization. Geochemistry, Geophysics, Geosystems 19, 2895-2914.

Brand, W.A., Assonov, S.S., Coplen, T.B. (2010) Correction for the ${ }^{17}$ O interference in $\delta^{13} \mathrm{C}$ measurements when analyzing $\mathrm{CO}_{2}$ with stable isotope mass spectrometry (IUPAC Technical Report). Pure and Applied Chemistry 82, 1719-1733.
Breitenbach, S.F.M. Mleneck-Vautravers, M.J. Grauel, A.-L, Lo, L., Bernasconi, S.M., Müller, I.A., Rolfe, J., GÁzqueZ, F., Greaves, M., Hodell, D.A. (2018) Coupled $\mathrm{Mg} / \mathrm{Ca}$ and clumped isotope analyses of foraminifera provide consistent water temperatures. Geochimica et Cosmochimica Acta 236, 283-296.

Burman, J., Gustafsson, O., Segl, M., Schmitz, B. (2005) A simplified method of preparing phosphoric acid for stable isotope analyses of carbonates. Rapid Communications in Mass Spectrometry 19, 3086-3088.

DaËron, M., Blamart, D., Peral, M., AfFeK, H.P. (2016) Absolute isotopic abundance ratios and the accuracy of $\Delta_{47}$ measurements. Chemical Geology 442, 83-96.

Daëron, M., Drysdale, R.N., Peral, M., Huyghe, D., Blamart, D., Coplen, T.B., LarTaud, F., Zanchetta, G. (2019) Most Earth-surface calcites precipitate out of isotopic equilibrium. Nature Communications 10, 429.

Defliese, W.F., Hren, M.T., Lohmann, K.C. (2015) Compositional and temperature effects of phosphoric acid fractionation on $\Delta_{47}$ analysis and implications for discrepant calibrations. Chemical Geology 396, 51-60.

DenNIS, K.J., SchraG, D.P. (2010) Clumped isotope thermometry of carbonatites as an indicator of diagenetic alteration. Geochimica et Cosmochimica Acta 74, 4110-4122.

Dennis, K.J., Affek, H.P., Passey, B.H., Schrag, D.P., Eiler, J.M. (2011) Defining an absolute reference frame for "clumped" isotope studies of $\mathrm{CO}_{2}$. Geochimica et Cosmochimica Acta 75, 7117-7131.

Ghosh, P., Adkins, J., Affek, H., Balta, B., Guo, W., Schauble, E.A., Schrag, D., EILER, J.M. (2006) ${ }^{13} \mathrm{C}-{ }^{18} \mathrm{O}$ bonds in carbonate minerals: A new kind of paleothermometer. Geochimica et Cosmochimica Acta 70, 1439-1456.

Guo, W., Mosenfelder, J.L., Goddard, W.A., EILer, J.M. (2009) Isotopic fractionations associated with phosphoric acid digestion of carbonate minerals: Insights from first-principles theoretical modeling and clumped isotope measurements. Geochimica et Cosmochimica Acta 73, 7203-7225.

JoHN, C.M., Bowen, D. (2016) Community software for challenging isotope analysis: First applications of 'Easotope' to clumped isotopes. Rapid Communications in Mass Spectrometry 30, 2285-2300.

Kele, S., Breitenbach, S.F.M., Capezzuoli, E., Meckler, A.N., Ziegler, M., Millan, I.M., Kluge, T., Deák, J., Hanselmann, K., John, C.M., Yan, H., LiU, Z., Bernasconi, S.M. (2015) Temperature dependence of oxygenand clumped isotope fractionation in carbonates: A study of travertines and tufas in the $6-95^{\circ} \mathrm{C}$ temperature range. Geochimica et Cosmochimica Acta 168, 172-192.

Kluge, T., John, C.M., Jourdan, A.L., Davis, S., CrawshaW, J. (2015) Laboratory calibration of the calcium carbonate clumped isotope thermometer in the $25-250^{\circ} \mathrm{C}$ temperature range. Geochimica et Cosmochimica Acta 157, 213-227.

Meckler, A.N., Ziegler, M., Millán, M.I., Breitenbach, S.F.M., Bernasconi, S.M. (2014) Long-term performance of the Kiel carbonate device with a new correction scheme for clumped isotope measurements. Rapid Communications in Mass Spectrometry 28, 1705-1715.

Meinicke, N., Ho, S.L., Hannisdal, B., Nürnberg, D., Tripati, A., Schiebel, R., MeCKLER, A.N. (2020) A robust calibration of the clumped isotopes to temperature relationship for foraminifers. Geochimica et Cosmochimica Acta 270, 160-183.

Müller, I.A., Violay, M.E.S., Storck, J.C., Fernandez, A., van Dijk, J., Madonna, C., BERNASCONI, S.M. (2017a) Clumped isotope fractionation during phosphoric acid digestion of carbonates at $70{ }^{\circ} \mathrm{C}$. Chemical Geology 449, 1-14.

MÜller, I.A., Fernandez, A., RadKe, J., van Dijk, J., Bowen, D., Schwieters, J., BERNASCONI, S.M. (2017b) Carbonate clumped isotope analyses with the long-integration dual-inlet (LIDI) workflow: scratching at the lower sample weight boundaries. Rapid Communications in Mass Spectrometry 31, 1057-1066.

MÜlleR, I.A., Rodriguez-Blanco, J.D., StORCK, J.-C., DO NASCIMENTO, G.S., Bontognali, T.R.R., Vasconcelos, C., Benning, L.G., Bernasconi, S.M. (2019) Calibration of the oxygen and clumped isotope thermometers for (proto-)dolomite based on synthetic and natural carbonates. Chemical Geology 525, 1-17.

PAsseY, B.H., Henkes, G.A. (2012) Carbonate clumped isotope bond reordering and geospeedometry. Earth and Planetary Science Letters 351-352, 223-236.

Peral, M., Daëron, M., Blamart, D., Bassinot, F., Dewilde, F., Smialkowski, N., Isguder, G., Bonnin, J., Jorissen, F., Kissel, C., Michel, E., Vázquez Riveiros, N., WAelBroecK, C. (2018) Updated calibration of the clumped isotope thermometer in planktonic and benthic foraminifera. Geochimica et Cosmochimica Acta 239, 1-16.

Petersen, S.V., Defliese, W.F., SAenger, C., Daëron, M., Huntington, K.W., John, C.M., Kelson, J.R., Bernasconi, S.M., Coleman, A.S., Kluge, T., Olack, G.A., Schauer, A.J., BainaI, D., Bonifacie, M., Breitenbach, S.F.M., Fiebig, J., Fernandez, A.B., Henkes, G.A., Hodell, D., 
Katz, A., Kele, S., Lohmann, K.C., Passey, B.H., Peral, M.Y., Petrizzo, D.A., Rosenheim, B.E., Tripati, A., Venturelli, R., Young, E.D., Winkelstern, I.Z. (2019) Effects of Improved ${ }^{17} \mathrm{O}$ Correction on Inter-Laboratory Agreement in Clumped Isotope Calibrations, Estimates of Mineral-Specific Offsets, and Temperature Dependence of Acid Digestion Fractionation. Geochemistry, Geophysics, Geosystems 20, 3495-3519.

Piasecki, A., Bernasconi, S.M., Grauel, A.-L., Hannisdal, B., Ho, S.L. Marchitto, T.M., Meinicke, N., Tisserand, A., Meckler, N. (2019) Application of Clumped Isotope Thermometry to Benthic Foraminifera. Geochemistry, Geophysics, Geosystems 20, 2090

Schauble, E.A., Ghosh, P., Eller, J.M. (2006) Preferential formation of 13C-18O bonds in carbonate minerals, estimated using first-principles lattice dynamics. Geochimica et Cosmochimica Acta 70, 2510-2529.

Schauer, A.J., Kelson, J., SAenger, C., Huntington, K.W. (2016) Choice of ${ }^{17} \mathrm{O}$ cor rection affects clumped isotope $\left(\Delta_{47}\right)$ values of $\mathrm{CO}_{2}$ measured with mass spectrometry. Rapid Communications in Mass Spectrometry 30, 2607-2616.

SCHMID, T.W., BERNASCONI, S.M. (2010) An automated method for 'clumpedisotope' measurements on small carbonate samples. Rapid Communications in Mass Spectrometry 24, 1955-1963.

UREY, H.C. (1947) The thermodynamic properties of isotopic substances. Journal of the Chemical Society (Resumed). The Royal Society of Chemistry 562-581.

van Dijk, J., Fernandez, A., Storck, J.C., White, T.S., Lever, M., Müller, I.A. Bishop, S., Seifert, R.F., Driese, S.G., KrYlov, A., LudVigson, G.A TuRCHYN, A.V., Lin, C.Y., WITTKOP, C., BERNASCONI, S.M. (2019) Experimental calibration of clumped isotopes in siderite between 8.5 and $62{ }^{\circ} \mathrm{C}$ and its application as paleo-thermometer in paleosols. Geochimica et Cosmochimica Acta 254, 1-20. 